\title{
The Development of Arkansas' International Trade: Problems and Progress
}

\author{
Gene E. Bigler \\ Hendrix College
}

Abstract: The importance of international exports for Arkansas' economy was recognized belatedly in the state; so, even though momentum was actually built in the 1950s, little additional progress was achieved until the late 1970s. This paper examines both the practical and structural conditions that have impeded the growth of Arkansas' exports and then reviews the progress that has been made in overcoming these obstacles. Contributions from the public and private sectors are considered, as well as problems of coordinating state and federal efforts in order to assist both the manufacturing and agricultural interests of the state.

The importance of international trade to the United States has become more apparent in recent years. The oil crisis of 1974 and 1979 demonstrated the high degree of dependence on foreign oil and also aroused concerns about continued access to foreign sources of other raw materials. The instability of the dollar in world money markets, a succession of hugh balance of payments, deficits, mounting tides of imports, and large investments by foreigners in farms and businesses have all led to greater attention to America's international economic relations.

Arkansas stands to gain much from an expanded share of international markets. Going international would help to insulate the state against a national recession or heightened national inflation. By basing the growth of its industries and agriculture at least partially on foreign markets, Arkansas need not be bound by sluggish growth in the rest of the country.

Yet some traditional American ways of doing international business and some of our ideas about ourselves and the rest of the world create serious obstacles to improving our current international economic situation. This paper explores these problems and some recent progress in overcoming them insofar as they pertain to Arkansas'. It 
will (1) review past export performance of the state and what might be termed the dynamics of export performance, (2) identify a series of practical obstacles for increasing exports, (3) assess the progress that has been or may be expected to be made in overcoming such problems, (4) examine a more intractable set of structural obstacles to Arkansas exports, and (5) discuss prospects for and success to date in surmounting these structural problems.

\section{The Dynamics of Arkansas' Export Performance}

Arkansas has been more involved in the export trade than most of its citizens realize. The state, 33 rd in population and 49 th in per capita income in the United States, ranked 25 th in total export value in the mid-1960s and held the same position in the mid-1970s ${ }^{2}$. Thus the state ranks ahead of many more populous and wealthy states, such as Oregon, Maryland, Kentucky, and Colorado. The 1976-77 value of Arkansas exports of about $\$ 1.5$ billion accounted for just over 6 percent of its manufacturing production and about one third of agricultural production. Furthermore, jobs were provided for about 14,600 Arkansans ( 8 percent of the industrial labor force) in 1976 for export manufacturing alone. The value of Arkansas exports was equal to about 13 percent of the state's total production(GDP) in 1976. Thus exports appear to have become more important to Arkansas than the nation as a whole, about 7 percent of national production.

The export performance of the state for the mid-1960s to mid1970 s period, even though the state held its rank, was not very dynamic. Over a 10-year period, its manufacturing exports grew by 104 percent, while national growth was 127 percent, and the average growth for ten similar states was 159 percent $^{3}$. Similarly, over the thirteen-year span from 1964 to 1977, Arkansas' agricultural exports grew by 158 percent while national growth was 198 percent and the average growth for seven comparable states was 183 percent $^{4}$. Clearly, exporting was not the sector that pushed the state's growth over this period, although the activity remained very important to the state.

The lower rate of growth in Arkansas' exports is easily explained: both the public and private sectors paid little attention to the activity. A 1964 study and plan for accelerating the economic growth of the state failed to mention any relationship that the state might have to the international economy. Indeed, reviewing that study today gives the impression that its authors were unaware that exporting was in fact 
development that emphasized forging stronger links to the national economy. As a result, the Arkansas Industrial Development Commission (AIDC), under the leadership of Winthrop Rockefeller, actively promoted industrial investment opportunities in the state for outsiders. This action, among others, probably enabled Arkansas to make the considerable progress that was achieved up to the national recession of the mid-1970s.

The only sustained impulses for exporting during the 1960 s seem to have come from two major linkages to the national economy. First, Arkansas subsidiaries of large national enterprises were exporting because of their ties to international oriented parent corporations. Second, the large agricultural surpluses of the state, particularly in rice, were already well integrated into national agricultural programs, such as Food for Peace, which utilized the international market as a shock absorber for domestic production cycles and as an instrument for foreign policy.

A new private sector drive for international trade arose in the early 1970s and led to the formation of the Arkansas Exporters' Round Table (AERT) in Little Rock. This effort seems to have come as a result of the exporting success of a few individual firms and because of the vision of a new link to the world that was inspired when the Arkansas River was opened for bulk transport. The most important success story was that of Jacuzzi, whose export manager, Ray Robbins, joined with visionaries such as Bill Shepard of Arkansas Power and Light and AI Pollard of the Brooks-Pollard Agency to initiate the Round Table. With less than a dozen members, the Round Table's first task was to spread the word about the potential to export. With the help of the Memphis office of the Department of Commerce, the AERT organized Arkansas' first World Trade Week program in 1973 to spread the word about Jacuzzi, Ward Bus, and other success stories. ${ }^{6}$

The private push for exports went on alone with only minimal public assistance for several years. The state government had not yet taken an interest in the activity, and Arkansans had to go to Memphis or Dallas to secure Department of Commerce help before a branch of the Dallas regional office was finally established in Little Rock. However, even as late as 1977, the advisory commission for the North TexasArkansas-Oklahoma regional office of the Industry and Trade Administration included only three Arkansans on its forty-seven member board. ${ }^{7}$ Furthermore, at times when private efforts met with success in 
already uncharacteristically important to the state. ${ }^{5}$ On the other hand, that study did begin an outward-looking approach to economic establishing nuts-and-bolts and how-to-do-it courses for potential exporters or in attracting important foreign visitors to the state, they did not always receive cooperation from public officials. ${ }^{8}$ The drive in the private sector had by the mid-1970s achieved such momentum that it not only encouraged other private actions but also established the need and value of a corresponding public effort.

The first public official to become convinced of the importance of strengthening the international linkages of the Arkansas economy in order to promote the state's growth appears to have been Frank White, who served under Governor David Pryor as director of the AIDC. After a tour of state offices in Europe by a group of Arkansas political leaders, White succeeded in convincing the General Assembly of the need to create an Arkansas office as well. The AIDC office in Brussels was originally intended to promote European industrial investments in Arkansas and the export of Arkansas products; however, the legislators decided in 1975 that the first task, which was in their view more closely related to job creation in Arkansas, should be emphasized in the Brussels office. They failed initially to fund a position for a trade promotion specialist in the Brussels office.

The public effort in the international arena was fully incorporated into overall state plans for economic development by the Pryor administration. In 1976 an updated version of the 1964 economic growth study showed the extent of change in some thinking in the state about Arkansas' relationship to the international economy. This 1976 study recommended actions to encourage foreign investment and to promote manufacturing and agricultural exports as well as international tourism. ${ }^{9}$ It also emphasized the pivotal role that the Brussels office should play in these activities and perhaps enabled Governor Pryor to succeed in expanding the funding for that office. Yet the Pryor administration and the first Brussels representatives, Robert "Bunny" Adcock and Waldemar "Valdy" Eichmann, both of Conway, faced a difficult task. They had to overcome negative stereotypes about the state among Europeans, excessive expectations about the number and speed with which European factories woild be established in the state, their own inexperience in the activity, an inadequate and even more inexperienced support staff in AIDC headquarters in Little Rock, and the fierce competition that about twenty other already well-established state offices in Europe gave them. 
The Bill Clinton administration took over in 1979 and created a more dynamic role for the state government in promoting Arkansas' exports. Governor Clinton reorganized and renamed the AIDC as the Department of Economic Development (DED). Director James Dyke and his staff deemphasized foreign investment in the state in order to place more resources in export promotion." Furthermore, the Marketing Division Office in Little Rock was restructured by its new director, Gary Smith, to provide support for and closer liaison with the Brussels office, where Eichmann succeeded Adcock as manager.'

The last aspect of the organizational structure for promoting Arkansas exports has been that contributed by the federal government Arkansas officials worked for a number of years to convince the Department of Commerce to upgrade the satellite office in Little Rock to a district office. In October 1979 the effort succeeded when veteran trade specialist, Robert Kistler, was named to organize the new five person headquarters in Little Rock.

Congressman Bill Alexander of Northeast Arkansas appears to have been most instrumental in convincing the Department of Commerce to create this new district Congressman Alexander also promoted the establishment of the Mississippi Valley International Trade Center (MVITC) in Jonesboro and convinced Commerce to provide a fult-time trade specialist, Pat Burns, to aid in the development of that Center. ${ }^{13}$ The MVITC, which, with local leadership, was only established in 1979 as a private, nonprofit corporation, will seek to broaden the export potential and opportunities of small and medium agricultural producers and provide alternatives to the currently constricted world-market outlets of Riceland Foods, Bunge, and other huge grain traders.'

The final factors which will influence the dynamism of Arkansas export drive are the production potential of Arkansas industry and agriculture and the conditions of the international marketplace. With the steady devaluation of the dollar over the last few years, most Arkansas products are already price competitive with foreign products. However, price is not the only relevant positive condition. The rapid growth and diversification of Arkansas industry over two decades have created a desirable product line, and there is evidence of a growing push for market diversification and expansion. ${ }^{15}$ Likewise in agriculture, the state's momentum may be increasing as returns on rice exports improve and as new markets for grains, such as sorghum and milo, are developed to maintain soybean productivity through the control of nematodes. ${ }^{16}$ 


\section{Practical Obstacles to Export Growth}

While 307 Arkansas manufacturing firms-out of just over 2,000 in the state-have at some time exported something, probably no more than a few dozen can really be called experienced. ${ }^{17}$ With respect to agricultural exports, experience is even more limited. The state probably exported over $\$ 800$ million in farm products last year, but most of these, even the crops of the majority of million-dollar sellers, were handled by Riceland or Bunge or one of four or five other large firms.

The first set of practical obstacles consists of attitudes and awareness. ${ }^{18}$ Many potential exporters are unaware of the potential foreign demand for their products, the lucrativeness and/or stability of many overseas markets, and the ways they could go about placing their products for export and then getting paid for them.

The problems of awareness do not, however, end when the potential exporter becomes comfortable with the idea of exporting. $\mathrm{He}$ must also accept such ideas as (1) that he may not make a killing on one deal, (2) that foreign tastes may require some change in color, texture, or packaging, (3) that costs for transportation, sales financing, and marketing may be much higher than he expects but that they will not necessarily make the product uncompetitive, (4) that the margins of overseas middlemen and retailers may be much higher than he expects, and (5) that he may have to penetrate a forest of red tape before he can get his product to the purchaser. ${ }^{19}$

Once the awareness problems have been resolved, the exporter must actually overcome the hurdles of getting his product into the hands of the foreign buyers and the money of the foreign buyers into his own pocket. First, he must locate a potential market and then the potential buyers within it. Such problems in the export area are more complicated than calling a Chamber of Commerce or Trade Association to get the names of wholesalers in the next state.

Second, the exporter must find a means of communicating with and evaluating the potential buyers he has located. While true that English is today's lengua franca for international trade, there are acutally very few countries where it is spoken by more than a few of the larger wholesalers, distributors, and retailers. If the Arkansas businessman does find a foreigner who can read his English language brochures, letters, and cables, he will have a very hard time when he receives a letter, contract, purchase order, or tender offer written in 
another language because there are few translation services in the state. $^{20}$ If either the buyer or the seller fails to understand the type of person- "Arky" or "Kraut" - that he is dealing with, phone calls, letters, cables, and even visits of salesmen to buyers may provide insufficient communication.

Next, the Arkansas producer must confront the problems of moving his product to the overseas purchaser. There is currently a single international freight-forwarding company in Arkansas, and that company - Worldwide - specializes in arranging shipping for Riceland and a very few other large exporters. ${ }^{21}$ Therefore, the potential exporter must locate connections in Memphis, New Orleans, Houston, or some other port or turn to one of only a half dozen relatively small export management firms within the state. ${ }^{22}$ Such firms can, however, help in arranging the transportation and insurance and in complying with foreign and American export licensing requirements. There still may be difficulty or additional cost in finding a lawyer with any knowledge of international law so that the contracts may be arranged or in finding a bank that can help with the financial transactions. ${ }^{2}$

\section{Progress in Overcoming the Practical Obstacles}

Such practical obstacles are noteworthy, but the progress made in overcoming them during the last few years is making them less discouraging to potential new exporters. The progress being made can be seen in two ways. First and most simply, the number of firms that have succeeded in making export transactions is growing rapidly, and because of such growth the supply of commercial support services (such as export management firms and translation services) is also beginning to grow. Second, at least three approaches to overcoming these practical obstacles have been or are being institutionalized within the state.

The first of these is the approach that has been instituted by the Arkansas Exporters' Round Table (AERT), which can be called "by sheer dint of example." The AERT brings together already successful exporters with other Arkansas businessmen who are only beginning to think about it. The successful exporters can thus share their experiences about how they got it done and how important exports are to their firm. For example, at a recent meeting of the AERT, a representative of Orbit Valve Company related how the exporting business of his firm had grown to account for about thirty percent of sales, and then an executive of A.O. Smith Company read a letter to the governor which 
praised the work of the Brussels office in securing a market for A.O. Smith products. ${ }^{24}$

The second approach is the "handholding technique" of the Marketing Division and Brussels office of the Department of Economic Development. This technique features one-on-one service from start to finish by DED staff in Little Rock and Brussels. DED staff help the prospective exporter over all the hurdles mentioned earlier. They also scout out potential markets and encourage firms to consider exporting and to locate potential Arkansas suppliers for product demands that they have received or induced in Europe. ${ }^{25}$

One evidence of the importance of the Brussels office as a communications link is the $\$ 1,000$-a-month telex bills that it generates on behalf of would-be exporters. Additional evidence that the approach is working can be found in the list of more than seventy firms that have used the office for market searches abroad or to conduct mailing campaigns or to arrange trade-fair participation or for personal services in making appointments and providing translations when Arkansas businessmen actually travel to Europe.

The last and newest approach for Arkansas is the one that is being fostered by the International Trade Administration (ITA) Department of Commerce, district office for Arkansas. This approach emphasizes "international marketing." Rather than primarily customizing service or emphasizing the motivation of exporters, ITA concentrates on providing packaged assistance of use, for example, to all potential exporters of pollution control equipment or to all potential sellers to the French wood-products market or to all probable users of maritime transport.

These three approaches are not totally separate or isolated from one another. Rather, the encouraging features of this multiplication of channels are that they, first, dovetail nicely to cover a wide range of needs with the efficiency of specialization and, second, are redundani only enough to insure that the job gets done. ${ }^{2}$

\section{Structural Obstacles to Export Growth}

The fact that more Arkansas producers have succeeded over the last few years in exporting more of their products does not mean that all of the important obstacles have been overcome. Some progress has been made, but the desired impact from increasing exports can be achieved only if exports become a sustained source of growth with ripple effects that can, for a state such as Arkansas, perform a leading 
sector role in the economy. Indeed, if exports provide only a short-term windfall or serve only as a fallback expedient, then their net effects may be negative because they could encourage waste or prevent technological or market adjustments or sustain inefficient producers.

The obstacles that must be overcome before exports can perform a leading sector role in the state economy are structural. That is, they are based on long standing traditions and legal, economic, and physical conditions. Therefore, the cooperation and resources of large numbers of persons, organizations, and institutions may be required to overcome them. These structural obstacles need to be identified and analyzed separately, for they are much more difficult to overcome.

Attitudes and values are very important in the structural category of problems, as they are in the practical category. In the latter case, however, the negative mind set is more engrained and manifests itself in more powerful ways than just reluctance, anxiety, or skepticism. The "get by" mentality that has been attributed to some Arkansans by a number of the interviewees for this study has been associated by them with attitudes that favor autarky, behaviors which emphasize fallback and windfall approaches to exports, and prejudices that support nationalistic rather than international values. ${ }^{28}$

One informant explained the "get by" mentality in relation to the high degree of economic deprivation that Arkansas has endured over the last fifty years. The Great Depression struck Arkansas especially hard. Just surviving became the primary task of Arkansas businessmen, farmers, and workers. The scarcity of material goods and financial resources forced Arkansans to learn to "get by" with the little that they had on hand and to be satisified with that.

Risk taking, accordingly, became a more fearful undertaking regardless of the promised return. Expansion of an ongoing enterprise was approached fearfully because there would be a great risk of losing the little one had to get by on. The legendary independence of the Arkansan also became linked to the need to survive during the Depression as a result of the puny outside efforts of the federal government to relieve the state's plight. Thus another interviewee stated: "They just thumbed their suspenders, built a fence around the state, and were content to be self-sufficient." 29

Two of the more important ramifications of this mentality are that businessmen may undertake exporting only (1) if they see almost no risk or a disproportionate return to their risk (both are windfall returns), 
or (2) because they have no other choice (a fallback expedient).

Arkansans have also failed to build up an educational or institutional structure that would support an increase in the international involvement of the state. The long internationalist leadership provided by Senator J.W. Fulbright for the rest of the country seems to have had little impact on his home state. The inadequacy of foreign language instruction and learning is a nationwide problem, but in Arkansas the rates are twice as low, and many of the world's most important and common languages are not even taught at the leading universities in the state. $^{30}$

Similarly, international political science, econimics, business, law, and other subjects are neglected to a surprising degree in Arkansas colleges and public schools. Along with this paucity of formal opportunities to develop internationalist attitudes, it is difficult for Arkansans to learn about the world informally because of the relatively small foreign enrollment in Arkansas schools, the low degree of foreign immigration to the state, and the insular geographic position of the state within the United States. The lack of any effort, comparable to that in exporting, to promote international tourism also misses an important opportunity to increase foreign contact, and tourism experts and recent experience in Florida and other states show that the return on investments to promote international rather than domestic tourism is greater. $^{31}$

All of these features of the state's institutional and intellectual structure tend to increase the difficulty of thinking internationally. Furthermore, these conditions may reduce the likelihood that Arkansas will perceive the need to support internationally oriented activities or that they will hold their political leaders accountable for not supporting such activities. Indeed, Senator Fulbright may have learned at some cost that the reverse is true. A recent newspaper article about the trip of several leading state officials to the Far East seemed by the emphasis placed on the cost of the trip to indicate the existence of suspicious rather than supportive attitudes about international activities. ${ }^{32}$ The trip achieved some important results, but these were obscured by the negative headline given the news story.

Even if all of the obstacles mentioned to this point were surmounted, it would still be difficult to achieve and sustain a much higher level of Arkansas exports for very long with the current logistical infrastructure. The transportation, service, communication, financial. 
organizational, and even legal infrastructure of the state and the nation have not been built to support an export-oriented economy.

One of the areas of greatest inadequacy is transportation. The United States depends heavily on trucking to move its goods, but trucking is simply too costly a mode of transport if it is used for the long, first leg of a journey that runs from the heartland to a coastal port before a still longer sea odyssey. Great progress was made during the 1960 s and 1970 s to increase the navigability of the rivers serving Arkansas. Since water provides by far the cheapest mode of transport for bulk goods-Arkansas' most important group of exports - this development is of great significance to the state. However, port facilities on the rivers are inadequate, and shortages of barges prevent full utilization of this source of cheap transportation for many agricultural commodities, forest products, lignate coal, and other goods. ${ }^{33}$ Also, the financial crisis of the Rock Island Railroad has created further problems in the second cheapest transportation network in the state.

Storage facilities are another vital component of the logistics of exporting Yet this vital link in the exporting chain has historically been provided only by the major international grain exporters. Therefore, small and medium-sized producers have nowhere to store and pool their grain prior to shipment abroad. even if they were to develop their own transportation and marketing systems. Moreover, greater economic benefits for the state are also missed because produce processing facilities are underdeveloped and many products are exported primarily as raw materials.

The key to meeting the state's requirements for better export logistics is additiona! physical investment but the reason for the low outlays for these facilities in the past is in large part due to organizational and financial deficiencies. The cooperative structure of Riceland Foods is, perhaps, the only successful Arkansas-based model of organization that has been used to overcome these problems. Little progress has been made to date on any alternative approach-although the MVITC is a promising start. Yet other organizational models, or more Ricelands, that can help smaller producers gain access to cheap transportation. storage, processing. financing. and marketing will have to be created before the state can fully exploit its exporting potential for agricultural and natural resources products.

Finally. considerable adjustments in traditional American foreign political and trade policies will have to be made before a truly dynamic 
export industry can be developed. One of the most pressing concerns of any potential importer, whether in Europe, Latin America, behind the Iron Curtain, or in Asia, is the security of supply and the continuity of after-the-sale service and replacement parts. As long as exports are a major tool of United States foreign political policy, it will be difficult for potential foreign buyers to rely heavily on American exporters. Furthermore, domestic policies related to agricultural production, pollution, safety, and other requirements that products must meet as well as rules related to business conduct and the taxing of overseas business and citizens, all constrain the growth of exports from Arkansas and the rest of the nation. ${ }^{34}$

\section{Progress in Overcoming the Structural Obstacles}

Steps to overcome the structural obstacles mentioned above are barely getting under way now, and it will be some time before their efficacy can be judged. The fact that most of the problems have been recognized and that action is being taken is a very encouraging sign.

The Mississippi Valley International Trade Center seems to have the potential to become an efficient export management agent for the smaller, and especially the non-rice, agricultural producers of Northeast Arkansas and perhaps even for a broader section of the Delta. Arkansas State University at Jonesboro has become involved in export promotion and service delivery in the export area for the region. Its president serves on the board of the MVITC, and several professors there recently completed an enlightening study of the trade promotion needs of the region. ${ }^{35}$ This group has already proposed the creation of an international studies curriculum at the university and an International Trade Institute to supply needed research and educational programs.

A second set of encouraging developments center on the more manufacturing oriented activities of Little Rock based programs. The Marketing Division of the DED is considering a new approach that would emphasize cooperation among a series of producers to promote a given product line, such as materials for furniture manufacturing, rather than the products of individual producers. Such an approach might not only increase the efficiency of the office's work but could also add organizational depth to exporting activities. Additionally, that office is planning a series of educational activities that would help reduce deficiencies in the supply of international legal, logistics, financial, and other types of expertise. The University of Arkansas at Little Rock has 
developed an undergraduate program in international studies, and additional programs, such as international business, are being considered. The Little Rock base of these activities at UALR should lead to a natural emphasis on manufacturing activities and provide complimentary services to those under consideration in Jonesboro.

The impetus that a larger federal commitment in Little Rock implies cannot be ignored. The Department of Commerce's vast overseas marketing network can pinpoint much more demand, provide more data, and assist marketing in more countries than the state could ever service. Furthermore, new efforts to coordinate international trade activities through the Department of Commerce, as mandated by the Trade Reorganization Act of 1979, could greatly facilitate the access of Arkansas exporters to credit-Export-Import Bank, Small Business Administration, or Overseas Private Investment Corporation-insurance, and other services. Finally, the federal government may, to a greater extent than either the state or private organizations, spur the creation of an exporters' lobby within the state. Such a lobby could generate sufficient demand to justify major infrastructural investments that the state needs or could influence the decision of federal agencies, such as the Army Corps of Engineers, to cooperate with or carry out needed projects.

The ultimate success of the state in overcoming the structural obstacles to a high level of exports will depend on the initiative of Arkansas' private businessmen and citizens. State and federal agencies can help, but as Kistler noted in his remarks to the author, ". . . we have closed down district offices before. . " Indeed, the "get by" mentality will not be changed by the actions of the public trade facilitators, nor will the number of college course offerings have much influence on whether more Arkansans study foreign languages or learn international law, nor will atomized, individual efforts and nationalistic attitudes stop the use of trade as a foreign policy weapon.

\section{Conclusion}

In any exploratory effort important questions and intriguing possibilities have had to be slighted. But at least the range of the issues that remain might be usefully raised in closing. First, there are value assumptions about the desirability of economic growth and, indeed, of export-led growth, i.e., greater international economic interdependence, that need to be examined explicitly. Second, the product 
types, regional distribution, industrial and corporate size characteristics, employment effects, and other aspects of export-induced economic growth need to be studied. Third, the potential for publicprivate conflict due to growing private dependence on public expor promotion activities or from public intervention in normally private business activities needs to be investigated. However, the author's encounter with this area of public-private interaction suggests an unusual degree of cooperation rather than conflict, so perhaps there is potential for more concertative, to use the French term, action between social sectors than is common in the United States. This observation raises a fourth area for exploration that contrasts with the third. Could increased business-government cooperation in the export sphere be generalized to other areas of the economy and lead to the type of general partnership which exists in France, West Germany, and Japan? Finally, what costs or problems might be created for Arkansas as a result of internationally versus domestically linked development?

\section{Notes}

Acknowledgments: A much appreciated faculty research grant from Hendrix College helped defray the costs of this research. Special thanks go (in no special order) to Robert Adcock, Al Pollard, Robert Kister Frank White, Rick Field. David Pryor, Elbert Jean, Pat Burns, Gary Smith, Jane Weaver, David Smith, Jim Oliver, Lynn Daniel, Rod McSherry, Lonnie Talbert, and several anonymous interviewees for their generous collaboration and the invaluable information the supplied for this study.

1. An earlier version of this paper was presented at the annual meeting of the Aikansas Poincal Socent Association. Fairfield Bay. February 1980. The contributions from the editor of this Journal and his anopstnes referees to this revised effor have greatly improved the product but the author remains respansible for at deficiencies that persist

2. U.S. Department of Commerce. "Arkansas" Expors." (Washington. DC. Industry and Trade Admich tration. State Expon Series. 1978). Tables 5 and 6 . Calculations on regrouped data uere performed by tio author.

3. Ibid Table 5

4. Ibid Table 6

5. Arkansas Economic Expansion Study Commission. Accelerating Economic Growth in Arkansas Litle Rock. 1964).

6. Interview with Al Pollard

7. North Texas. Oklahoma. Arkansas District Export Council. Export Information Manual for Arkussa Louisiana. New Mexica. Oklahoma and Texas. 2nd ed. (Dallas. U S Deparment of Commerce 1978 . 8. An anonymous interiewee related a story about a visit to the state by a foreign trade minister who was belf by a prominent Arkansan that things were going just fine in the state and that there was no need for ousten a come in and mess things up.

9. Arkansas Economic Development Study Commission. Report and Recommendations Arkans: Economic Development. A Design for Future Growth i Little Rock. 1976)

10 Intervews with Rober Adiock and Jane Weaver

11. Interview with Gary Smith See also. Jane Blotzer. "Economic Office To Stas Put Clinton Dene Transter." Arkansas Democrac January 19.1979, and "State Lands Foreign Indusery. Arkansas Gazeme. 
Februar 23, 1978 The Brussels office has traditionally gone beyond a narrow definition of its mission. For instance $\|$ succed ded in helping Lynndále Co. reach production licensing agreements with foreign firms because I yndale woud furnaces are not a competitive export (because of transportation costs) in spite of their advanced icchoology

1? Frponen who were interviewed lauded the cooperation between the offices.

13 Congessman Alexander has a superb reputation in the exporting community. His influence with the Department of Commerce is attributed to his positions on the House Appropriations Sub-Committee. which merseas the department. and as Deputy Majority W'hip.

Pat Burns. who is a member of the IT A Little Rock staff, nonetheless. works primarily with the MVIC in the Jonesburo areal

If Bill Alexander. "An Arkansas Congressman in China." Arkansas Times, February 1979.

is Aikansas Imploymeni Security. Division. Arkansas' Industrial Progress: $1950-1972$ (Little Rock. 14731

16. Ariansas Farm Bureau Federation. A Profile of Arkansas Agriculture (Little Rock. 1979). p. 18.

17. Estimates by informed observers. Also see the 1978 Directory of Arkansas Manufacturers.

18. Jane Weatert an crmon marketing officer in the Brussels Office of the DED) related the following anecdote whe AERI mecting on Prehruary 1 3.1980. The Brussels office received a request for bids from Arkansas tent makers on a supply contract in Europe. The Little Rock office of the DED then identified and contacted tent maics in the stale and offered its assistance if any of the companies would be interested in making an offer. One of the ene mahers ieplied "We ain' sellin tents to no foreigners."

1.) These monts summarize the ohservations made to the author by experienced exporters and export peranoters

21) The 1978 Manual ciled in note 8 above listed only four services that offered French. German. and Italian. A later manual ciles sir senices offering four languages: see Ozark Regional Commission. An International Traide Reference Guide and Senices Directory for The Ozarks Regional States (Little Rock. 1979).

2) Private communication w the author from Jim Oliver, a former employee of Worldwide. who now works for the () zarh Regunal Commission in export promotion activities.

$\because$ Ohsenations made by exporters in personal interviews.

2i Several informants noted the ahsence of specialized lauyers. They also noted that only four banks in the siate all in I ilile Rxik have export departments. The planners of one export promotion conference reported that thes cunsudered requinng interesied manufacturers to bring their bankers to the conference. but they later tecided apainst the idea hecause of fears that attendance would be poor.

is Personal when ation by the author of the AERT meeting of February 13. 1980. at the Coachman's Inn in In:ie Rini is

25 - The Repum on Actulles of the International Marketing Division. June 1. 1979 to December 31. 1979* (memeranhed). Lutele Rock. Arkansas. Department of Economic Development. n.d) Also. see note 18 above. 2h Ihid.

27 The disimgushed Isracli public administration specialist. Yehezkel Dror. is the originator of this theory of colindancy The author learned its truth while working with Dror in Venezuela.

is Nieastone source, an anonymous reviewer of this paper. felt that the "get by" mentality was declining in so tat as Amenican self suficiency is concerned.

2.) Prusate communication to the author from Dr. Lonnie Talbert. dean of the School of Business at Arkansas Sixie Universits I do not think that Dean Talbert's reference is related to the earlier isolationist concept of a ience dround the stale that was used by Dr. Charles Brough in his gubernatorial campaign of 1916 . The phrase "gei hy mentalits was suggested in the author by Al Pollard

10 Remeri S McCord. "Siudy Bares U.S Ignorance on Foreign Languages." The Arkansas Democrat. Pincrian 6. 1080

11 A recent study on courism desclopment for the state neglects. just as did the 1964 study of economic devehpment in menion the intemational dimension. see Frank H. Troutman and John H. Opitz. Economic Impaci of Trabel and Tourism in Arkansas (Little Rock: Industrial Research and Extension Center. Un:iessis of Aikansas. 1976)

3? Clinion Tip to Far Fast Cost $519.489 . "$ Arkansas Gazette. November 30. 1979.

33 Ratrinad hopper cars are also. according io knowledgeable specialists, in shon supply and usually get monomolized hy the bie erain traders.

14 "Adfress by Senator Mathias on Deseloping a Sound U.S. International Trade and Monetary Position." Congressional Record. bol 125. no. 181 (Decemher 17. 1979). 